\title{
Chironomids also favour fermented products: an observation of chironomids dwelling in rotten apples
}

\author{
Ladislav Hamerlík, Michaela Barbieriková and Peter Bitušík
}

Faculty of Natural Sciences, Matej Bel University, Tajovského 40, SK-974 01 Banská Bystrica, Slovakia

E-mails: 1adislav.hamerlik@gmail.com, m.barbierikova@gmail.com, peter.bitusik@umb.sk

Chironomids are known to be extremely versatile in utilizing food sources and colonizing diverse habitats. This is probably one of the reasons for their extreme distribution. They often occupy surprising habitats and feed on unexpected sources. Such an uncommon food source for aquatic Chironomidae is fallen fruits in streams and lakes. To the best of our knowledge such feeding habits have only been reported from South America, where larvae of the genus Endotribelos are widespread and common dwellers of fruit tissues of several tree species in forested streams (Roque et al. 2008).

In the present short communication we report chironomids dwelling in fallen rotten apples floating on the surface of an urban pond in Slovakia. The study pond (Fig. 1a) is situated in the urban area of Banská Bystrica (central Slovakia, 48 $44^{\prime} 29.03$ " N, 1907'26.30” E, $401 \mathrm{~m}$ a.s.1.) and it has an area of $\sim 15 \mathrm{~m}^{2}$ with a max depth of $1 \mathrm{~m}$. The pond harbours aquatic plants (Myriophyllum, Nymphaea, Typha) and a population of Koi carp (Cyprinus carpio haematopterus). There are several apple trees close by the pond from were apples fall into the water (Fig. 1b). During a standard limnological investigation of the pond in August 2016 we noticed the presence of chironomid larvae inside an apple floating on the surface. Therefore we collected, sectioned and investigated 11 apples to see whether it is a common food/habitat for chironomid larvae (Fig. 1c).

In the apples examined, a total of 21 larvae of three taxa were found: Endochironomus tendens (12 individuals; Fig. 1d), Cricotopus cf. sylvestris (5 ind.) and Polypedilum sp. (4 ind.). Moreover, a pupa of $E$. tendens was recorded inside one of the fruits. Nine out of 11 apples contained chironomid larvae and their number varied from 1 to 4 with an average of 1.9 larvae per apple. Some specimens, however, could have been overlooked during the sectioning of the fruits. Apples that were previously undisturbed by birds did
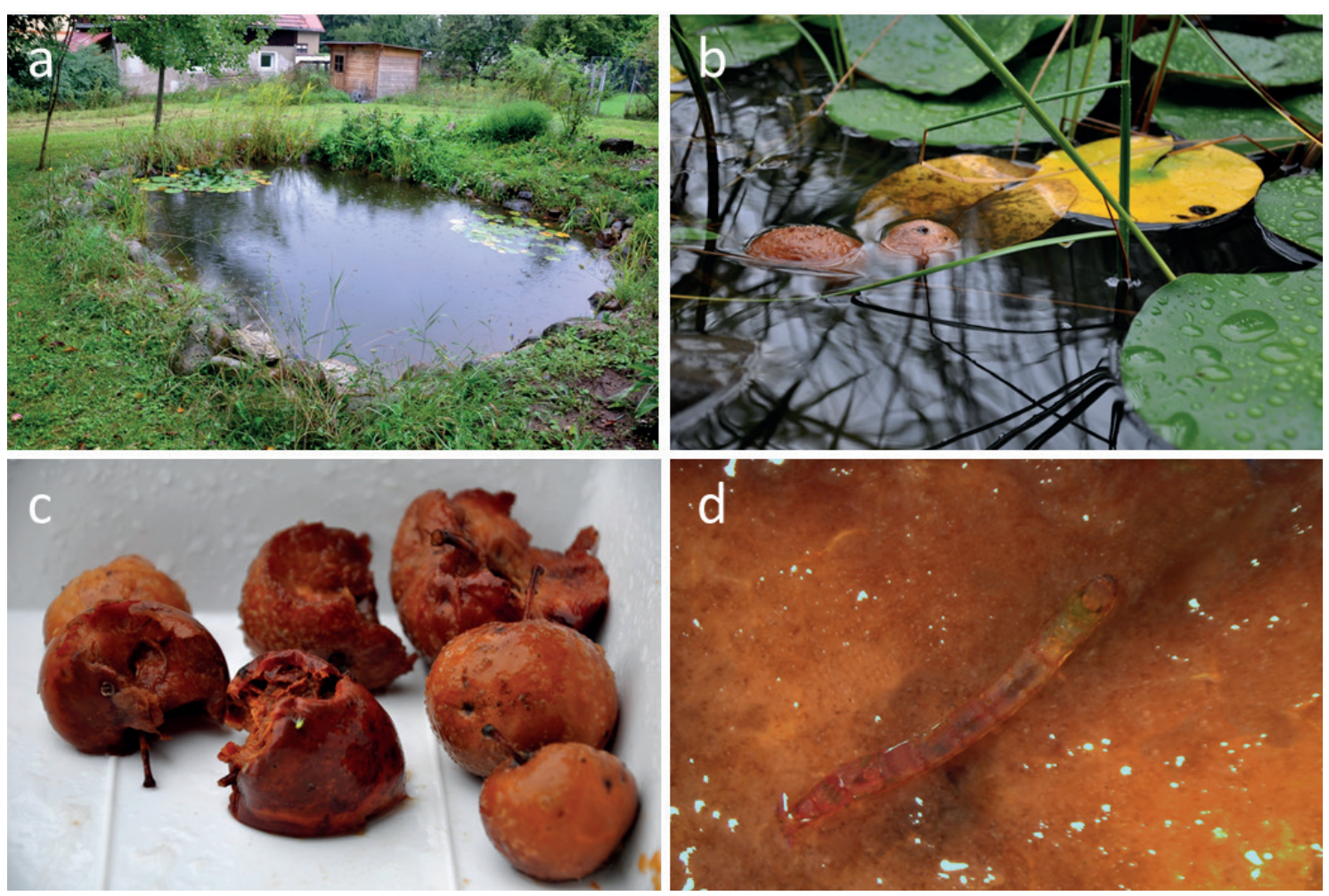

Figure 1. Pictures of the study pond (a), rotten apples floating on the surface (b), some of the apples before sectioning (c), and a larva of Endochironomus cf. tendens found inside the apple (d). Photo L. Hamerlik. 
not contain larvae, while disturbed apples at a high stage of putrefaction seem to contain more individuals. In general, all the larvae were found in the parts with softer tissues of the fruits.

It is questionable, if the larvae use the apples as food source or shelter from predators. Nevertheless, the current knowledge of the ecology of the recorded taxa and the gut content of the larvae suggest that they are likely to feed on the soft tissues of the fruit. Due to their high and balanced nutrition value some fruits can represent a valuable food resource for chironomid larvae (Roque et al. 2008). Moreover, microbial decomposition probably makes the fruits easier to colonize and digest for chironomid larvae, which is in accordance with our findings. In the Neotropical region only larvae of one genus (Endotribelos) are known to dwell in fallen fruits. According to Roque et al. (2005) the reason for that are poor aerobic conditions inside the fruits during decomposition and the presence of allelopathic substances in many Neotropical plants (Roque et al. 2008). In our study, larvae of as much as three taxa were found in the fallen apples. However, more research is needed to figure out, whether this is a consequence of the lack of specific allelopathic ingredients in the fruit or simply the generalist life strategy of chironomids of the temperate zone (as opposed to the specialists in the tropics).

Except for its common habitat, such as surface of leaves, Moller Pillot (2009) observed larvae of Endochironomus tendens penetrating into soft plant tissues or damaged plants and other authors (see Moller Pillot 2009 and references therein) found the larvae in or on decaying plant material. Larvae of Cricotopus sylvestris are opportunists feeding on available food, be it green algae, diatoms, detritus or living and dead animals, even though they are not active predators (Moller Pillot 2003). Larvae are also considered a pest of rice damaging roots and leaves of rice seedlings in China (Wang 2000) but also in Europe (Ferrarese 1992).

Our findings underline the notorious feeding flexibility of chironomid larvae. The high frequency of occurrence indicates that rotten fruits may play an important food source for some opportunistic aquatic chironomids. Moreover, such a habitat probably also serves as shelter from fish predators.

\section{Acknowledgement}

The authors are grateful to Martin Spies for his helpful notes on the topic. This paper was supported by projects ITMS 26210120024 "Renewal and development of infrastructure for ecological and environmental research at UMB" and by the Slovak Research and Development Agency under the contract No. APVV0059-11.

\section{References}

Ferrarese, U. 1992. Chironomids of Italian rice fields. - Netherland Journal of Aquatic Ecology 26: 341346.

Moller Pillot, H.K.M. 2009. Chironomidae Larvae, Volume 2: Biology and Ecology of the Chironomini. KNNV Publishing, Zeist, The Netherlands, 270 pp.

Moller Pillot, H.K.M. 2013. Chironomidae Larvae Volume 3: Biology and Ecology of the Aquatic Orthocladiinae. KNNV Publishing, Zeist, The Netherlands, $270 \mathrm{pp}$.

Roque, F.O., T. Siqueira and S. Trivinho-Strixino 2005. Occurrence of chironomid larvae living inside fallen-fruits in Atlantic Forest streams, Brasil. - Entomología y Vectores 12: 275-282.

Roque, F.O. and S. Trivinho-Strixino 2008. Four new species of Endotribelos Grodhaus, a common fallen fruit-dwelling chironomid genus in Brazilian streams (Diptera: Chironomidae: Chironominae). - Studies on Neotropical Fauna and Environment 43: 191-207.

Wang, X. 2000. Nuisance midges recorded from China. - In Hoffrichter, E.O. (ed.) Late $20^{\text {th }}$ century research on Chironomidae. Shaker Verlag, Aachen: 653-658.

Article submitted 25. August 2016, accepted by Peter H. Langton 26. August 2016, published 29. August 2016. 